\title{
Application of geophysical approach to highway pavement failure: a case study from basement complex terrain southwestern Nigeria
}

\author{
Charles I. Adenika ${ }^{*}$, Emmanuel A. Ariyibi ${ }^{1}$, Musa O. Awoyemi ${ }^{1}$, Adebiyi S. Adebayo ${ }^{2}$, Oluwaseyi A. Dasho ${ }^{1}$ \\ and Emmanuel O. Olagunju ${ }^{3}$
}

\section{*Correspondence:}

cadenika@yahoo.com

${ }^{1}$ Department of Physics and Engineering Physics, Obafemi Awolowo University, Ile-lfe, Nigeria

Full list of author information is available at the end of the article

\begin{abstract}
Geophysical survey involving Schlumberger Vertical Electrical Sounding, 2-D imaging dipole-dipole technique and ground magnetic method were carried out along Ibadan-Ife Highway located in the Precambrian Basement Complex of Southwestern, Nigeria to examine the geological factors responsible for Highway pavement failure. This was with the view to detailing the subsurface geoelectric sequence, mapping the subsurface structural features within the sub-grade soil and delineating the bedrock relief as a means of establishing the cause(s) of the road pavement failure. The geoelectric sections, 2-D resistivity structures and modeled magnetic profiles revealed that the stable segments were founded on a shallow/outcropping basement near homogeneous substratum devoid of major geological features while linear features suspected to be fault/fractured zones, buried stream channels, bedrock depressions and lithological contacts were identified beneath the failed segments of the highway pavement. The geoelectric sections generally identified four geologic layers comprising the topsoil, weathered layer, partly weathered/fractured basement and fresh bedrock. Thus, the failed portions of the road are probably precipitated by very thick and low resistive substratum (clay) beneath the highway pavement and the identified suspected linear features are the major geological factors responsible for the highway pavement failure.
\end{abstract}

Keywords: Geophysical survey, Geological features, 2-D resistivity structure, Substratum

\section{Introduction}

Road pavement failure in Nigeria has become a common occurrence especially after construction. Road pavement which is described as a structural materials seated upon sub-soil layers [25], is supposed to be a continuous stretch of asphalt laid for a smooth ride or drive, but discontinuity in the road network resulting in cracks, potholes, bulges and depressions gives rise to road failure $[3,12]$. Poor drainage network, poor construction materials, bad design, usage factor are some of the factors considered as responsible for these failures. Geological factors are rarely considered as precipitators of road failure even though the highway pavement is seated on geological earth materials (Momoh

(c) The Author(s) 2018. This article is distributed under the terms of the Creative Commons Attribution 4.0 International License (http://creativecommons.org/licenses/by/4.0/), which permits unrestricted use, distribution, and reproduction in any medium, provided you give appropriate credit to the original author(s) and the source, provide a link to the Creative Commons license, and indicate if changes were made. 


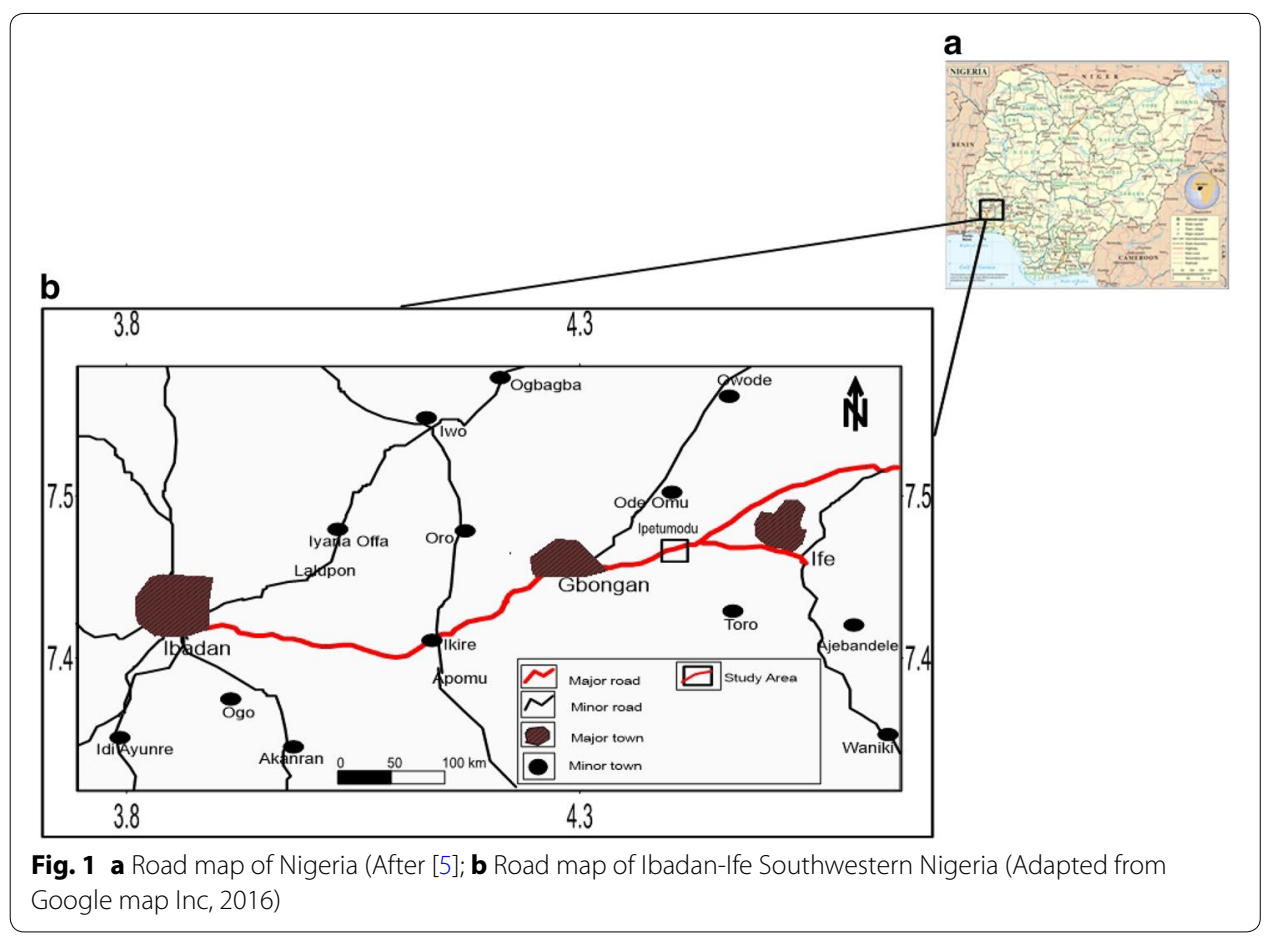

et al. [13]). This is due to non-appreciation of the fact that proper design of highway requires adequate knowledge of subsurface conditions beneath the highway route. The non-recognition of this fact has led to loss of integrity of many highway routes and other engineering structures across the country $[17,19]$. The spate of failure of the highway has been of major concern to the governments and all stake-holder because this has led to loss of lives, properties and undermine economic and social development of the country. Other previous studies have shown that the reliability of the road pavement can be damaged by the existence of geological features and/or engineering characteristics of the underlying geologic/geoelectric sequences $[1,4,14,22]$. It is hence vital for engineers to carry out pre-design investigations of engineering sites.

The research efforts to investigate the effect of the geological factors in terms of the nature of the subsoil, the near surface structures and the bed rock structural disposition as likely causes of failures along the Ibadan-Ife highway. The study utilized integrated geophysical investigations. Geophysical surveys are efficient and cost-effective in providing geotechnical information since they combine high speed and appreciable accuracy in providing subsurface information over large areas $[11,16,18]$.

\section{Site description and geological setting}

The Ibadan-Ife highway serves as a major link from the southwest to the northern and eastern parts of the Country. The study area (Fig. 1) is located between Latitudes $7^{\circ} 25^{\prime}$ to $7^{\circ} 35^{\prime}$ and Longitudes $4^{\circ} 20^{\prime}$ to $4^{\circ} 35^{\prime}$ and it covers about $4.0 \mathrm{~km}$ between AkinlaluAkinola area. The study area has an elevation that falls within the range of 215-232 $\mathrm{m}$ above the mean sea level. The study area experiences two seasons, the dry and wet (rainy) seasons [10]. The rainy season starts during the months of March-April and lasts till around October. The mean annual rainfall ranges between 1270 and $1524 \mathrm{~mm}$ 


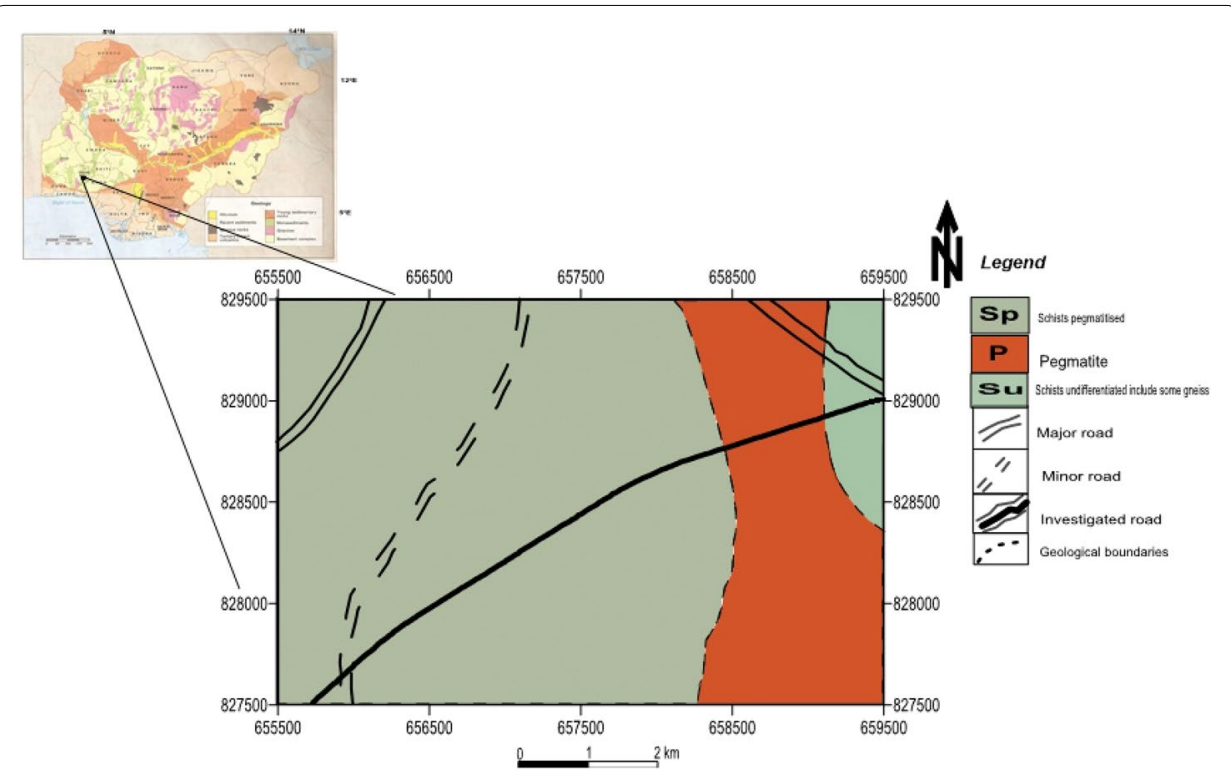

Fig. 2 Geology map of Nigeria (After [5] and Geology of the Study Area (Adapted from [6])

Federal Survey [9]. The relative humidity is about $60-85 \%$ from November to March, and about $80-90 \%$ around August. The mean temperature varies between 27 and $31{ }^{\circ} \mathrm{C}$. According to the Federal Survey [9], the area lies in the rain forest. The vegetation is dense and made up of broad-leaved trees that are mostly evergreen. Geologically, the study area is underlain with Schists-pegmatitised, Pegmatite and Schists undifferentiated (Fig. 2). The underlying rocks in the study area belong to the slightly migmatised to unmigmatised para-schists and meta-igneous rocks which constitutes one of the major rock units of the Precambrian Basement of the southwestern Nigeria [15, 20].

\section{Materials and methods}

Integrated geophysical investigation involving the use of magnetic and electrical resistivity methods were adopted for the study. Four geophysical traverses with length varying between 200 and $300 \mathrm{~m}$ were established across both the stable and failed segments of the road pavement within the study area (Fig. 3).

\section{Magnetic survey and data acquisition}

Magnetic method is the oldest geophysical exploration method used in prospecting. It measures variation in the Earth's magnetic field caused by changes in the subsurface's geological structure or the differences in near-surface rocks' magnetic properties. The relationship between magnetic fields and the magnetization within materials [23] is expressed by Eq. (1):

$$
\begin{aligned}
\boldsymbol{B} & =\mu_{0}(H+M) \\
\mu_{0} & =4 \pi \times 10^{-7} \mathrm{~Wb} / \mathrm{Am}^{-1}
\end{aligned}
$$

where $\boldsymbol{B}$, the magnetic induction is the total flux of magnetic field lines through a crosssectional area of a material, $\mu_{o}$ is the permeability of free space $\left(4 \pi \times 10^{-7} \mathrm{~Wb} / \mathrm{Am}\right), \mathrm{H}$ 


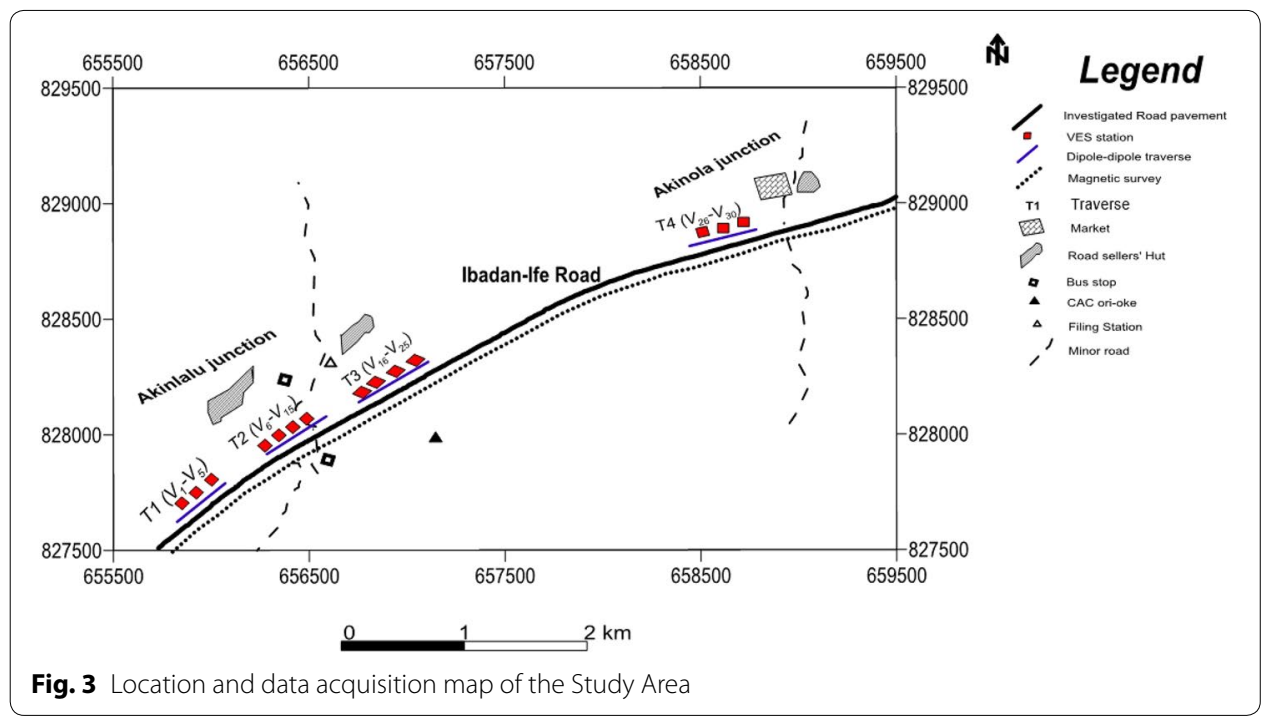

is the magnetic field applied to the material and $M$ is magnetization or response of the material to the applied magnetic field. Magnetic susceptibility $(\boldsymbol{k})$ is another important parameter, the relationship between magnetic induction $\mathrm{B}$, magnetizing force $\boldsymbol{H}$ and susceptibility $\boldsymbol{k}[21]$ is given as:

$$
\boldsymbol{B}=\mu_{0} H(1+K)
$$

where $\boldsymbol{B}$ is in tesla, $\boldsymbol{H}$ is given in amperes/metres and $\boldsymbol{k}$ is dimensionless in SI units.

Magnetic traverses were carried out along SW-NE direction. Magnetic stations were established at 5 and $10 \mathrm{~m}$ intervals along the 200 and $300 \mathrm{~m}$ traverses, respectively. Magnetic data were corrected for diurnal variation and offset using standard method. Magnetic data were presented as profiles which were qualitatively and semi-quantitatively interpreted by visual inspection and using Winglink modeling software, respectively.

\section{Electrical resistivity survey and data acquisition}

The electrical resistivity method involves the determination of subsurface resistivity distribution by taking ground surface measurements. This requires passing electrical current $(I)$ into the ground by means of two electrodes and the potential difference $(\Delta V)$ is measured between another pair of electrodes. Its apparent resistivity is represented by Eq. (3) [23]:

$$
\rho_{a}=\frac{\Delta V}{I} G
$$

where $\rho_{a}$ the apparent resistivity and $\mathrm{G}$ is the geometric factor which value depends on the electrode array's configuration. For vertical electrical sounding (VES) technique involving the Schlumberger array with a four electrode configuration (Fig. 4a), the apparent resistivity value is calculated using the Eq. (4).

$$
\rho_{a}=\frac{\pi R\left(\frac{A B}{2}\right)^{2}}{M N}
$$



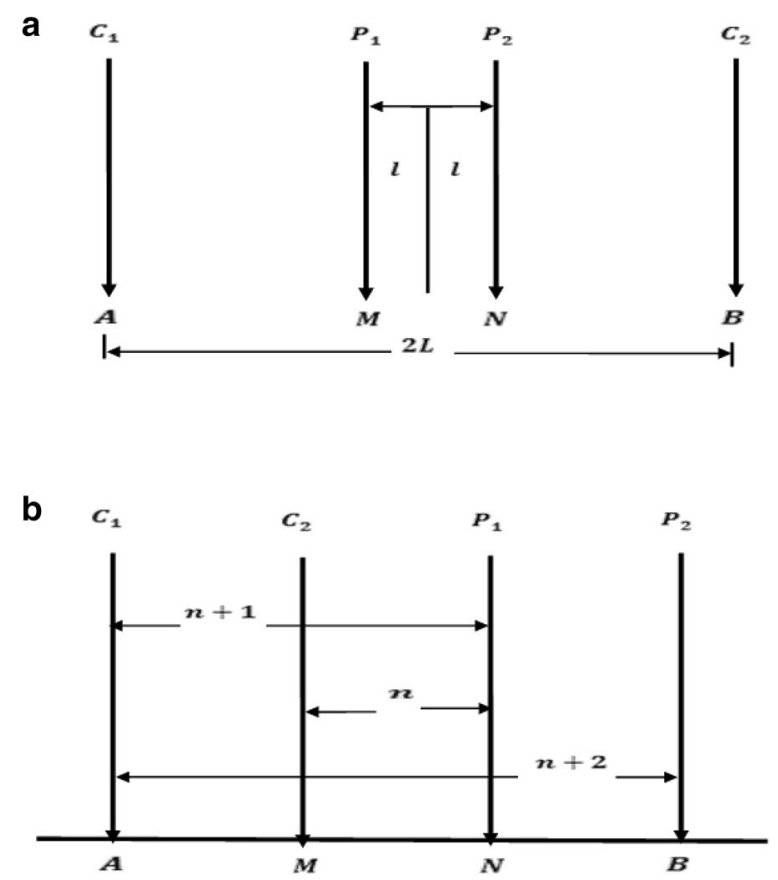

Fig. 4 a Typical Schlumberger electrode configuration, b Dipole-Dipole electrode configuration (After [23])

where $A B$ is current electrode spacing, $M N$ is potential electrode spacing, $R$ is electrical resistance and $\pi$ is a constant equal to 3.142; from the expression in Eq. (4) i.e. for Schlumberger array, the distance between the potential electrodes is small compared to the distance between the current electrodes.

In the case of dipole-dipole array (Fig. 4b) which is also referred to as combined horizontal profiling and vertical electrical sounding; its apparent resistivity is given by the Eq. (5):

$$
\rho_{a}=-\pi \operatorname{Rna}(n+1)(n+2)
$$

where $n$ is the expansion factor and $\mathrm{R}$ is electrical resistance.

The electrical resistivity method adopted two field techniques-vertical electrical sounding (VES) involving the Schlumberger array and 2-D electrical imaging using dipole-dipole technique.

Thirty (30) VES using the Schlumberger array were carried out at stations constrained by the 2-D resistivity images. The VES station spacing varied between 30 and $40 \mathrm{~m}$ while the half current electrode spacing $(\mathrm{AB} / 2)$ varied between 1 and $100 \mathrm{~m}$. The VES data were presented as type curves. The VES type curves were interpreted quantitatively by partial curve matching and computer iteration technique using WINRESIST software [24]. The interpretation results (layers resistivities and thicknesses) were used to generate the geoelectric Sections.

2-D resistivity data acquisition were carried out using dipole-dipole array. Dipole spacing of 5 and $10 \mathrm{~m}$ were adopted along the 200 and $300 \mathrm{~m}$ traverses, respectively. A dipole-dipole expansion factor of $\mathrm{n}$, varying from 1 to 5 was adopted. The dipole-dipole data were inverted into 2-D resistivity images using DIPPRO [8] software. 

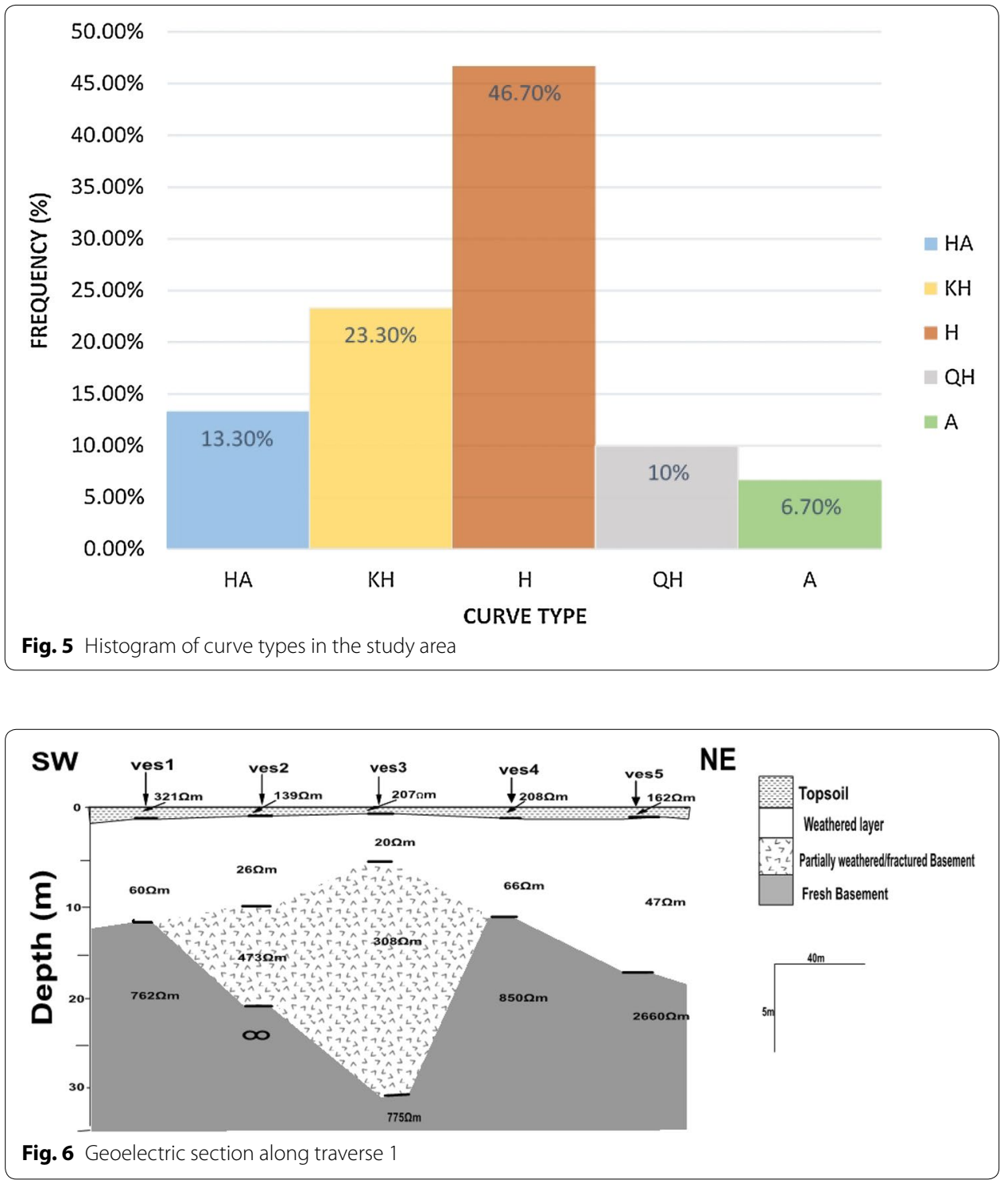

\section{Results and discussion}

\section{Electrical resistivity interpretation}

The results of the processed electrical resistivity are presented as sounding curves, geoelectric section and 2-D resistivity structures. The depth sounding curves vary from simple A: an ascending curve $\left(\rho_{1}<\rho_{2}<\rho_{3}\right)$ and H: Bowl curve $\left(\rho_{1}>\rho_{2}<\rho_{3}\right)$ type, to a more complex QH $\left(\rho_{1}>\rho_{2}>\rho_{3}<\rho_{4}\right)$, HA $\left(\rho_{1}>\rho_{2}<\rho_{3}<\rho_{4}\right)$ and $\mathrm{KH}$ $\left(\rho_{1}<\rho_{2}>\rho_{3}<\rho_{4}\right)$ type. The $\mathrm{H}$-type is the dominant type curves with a percentage frequency of occurrence of $46.7 \%$ (Fig. 5). The series of 1-D VES interpretation results [2] are assembled into geoelectric sections.

\section{Geoelectric section}

Figure 6 relates VES 1-5 along SW-NE direction. Four lithological layers comprising the topsoil, weathered layer, partially weathered/fractured basement and fresh 


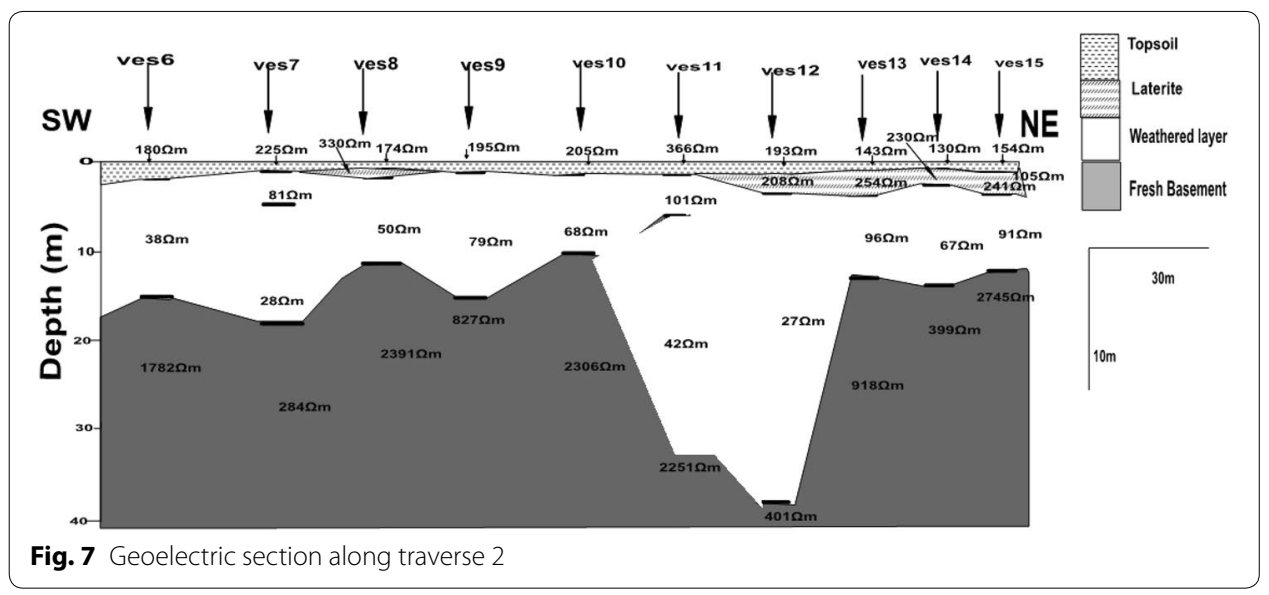

basement were delineated. The topsoil composes of sand/lateritic sand with resistivity variation of $139-324 \Omega \mathrm{m}$ and the thickness of $0.6-1.1 \mathrm{~m}$. The second geoelectric layer is weathered layer with resistivity variation from 20 to $66 \Omega \mathrm{m}$ while layer thickness varies from 5.4 to $17.0 \mathrm{~m}$. The weathered layer is typically composed of clay. The third layer is partially weathered/fractured basement. The layer resistivity varies from 30 to $473 \Omega \mathrm{m}$ while the layer thickness varies from 11.5 to $25.8 \mathrm{~m}$ localised at VES 2 and VES 3. The fourth layer is fresh basement with resistivity varies from 762 to $\infty \Omega \mathrm{m}$. The depth to basement varies from 11.7 to $31.9 \mathrm{~m}$. The basement depression is noticed at VES 2 and VES 3 and relief is undulating.

Figure 7 shows the geoelectric section relating VES 6 to VES 15 along SW-NE direction. Four lithological layers comprising of topsoil, laterite, weathered layer and fresh basement were delineated. The topsoil is composed of clayey sand/sand/lateritic sand with resistivity varying from 180 to $366 \Omega \mathrm{m}$ and the layer thickness varying from 0.7 to $1.9 \mathrm{~m}$. The second layer is laterite with resistivity varying from 208 to $330 \Omega \mathrm{m}$ and the thickness varying from 2.0 to $4.2 \mathrm{~m}$. The weathered layer is composed of clay with the resistivity varying from 28 to $101 \Omega \mathrm{m}$ and the thickness varying from 7.9 to $36.1 \mathrm{~m}$. The fourth geoelectric layer is the fresh basement. The layer resistivity varies from 284 to $2745 \Omega \mathrm{m}$. The depth to basement varies from 11.1 to $39.4 \mathrm{~m}$. The overburden is generally thick and thickest at VES 11 and VES 12 . The basement relief is uneven. The failed segment of the road pavement at southwestern flank on which VES 6 to VES 10 comprises of thin topsoil with mean resistivity and thickness of $196 \Omega \mathrm{m}$ and $1.2 \mathrm{~m}$, respectively. The weathered layer with mean resistivity and thickness of $53 \Omega \mathrm{m}$ and $11.9 \mathrm{~m}$, respectively, indicates clay composition which may account for the failure of the road pavement segment. The stable segment of road pavement at northeastern flank on which VES 11 to VES 15 composed of thin topsoil with a mean resistivity and thickness of $197 \Omega \mathrm{m}$ and $0.8 \mathrm{~m}$, respectively. Beneath the thin topsoil is lateritic layer with a mean resistivity and thickness of $233 \Omega \mathrm{m}$ and $3.3 \mathrm{~m}$ which actually account for the stability of this segment. The weathered layer has a mean resistivity and thickness of $65 \Omega \mathrm{m}$ and $18.5 \mathrm{~m}$, respectively. The basement depression under VES 11 and VES 12 may cause failure in the road pavement segment, but the presence of the lateritic layer and the high resistive topsoil still account for its present stability. 


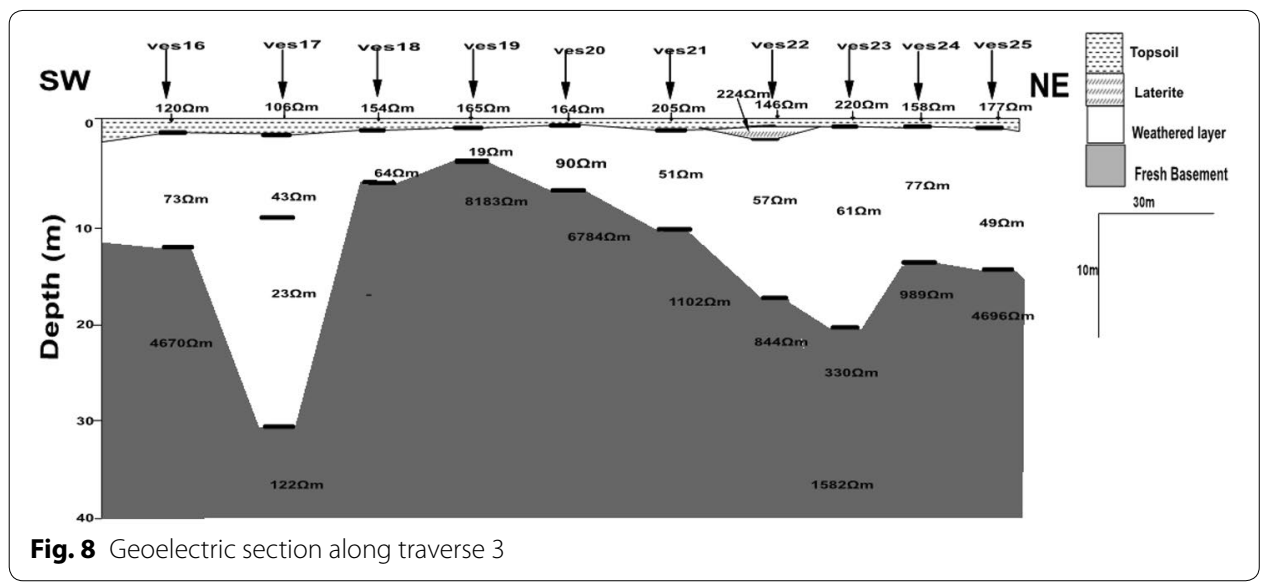

Figure 8 shows the geoelectric section relating VES 16 -VES 25 along SW-NE direction. Four lithological layers comprising of topsoil, laterite, weathered layer and fresh basement were also delineated. The topsoil resistivity varies from 106 to $220 \Omega \mathrm{m}$ while the layer thickness varies from 0.6 to $1.7 \mathrm{~m}$. The topsoil is composed of clayey sand/ sand. Beneath the topsoil is laterite with resistivity and thickness of $224 \Omega \mathrm{m}$ and $1.9 \mathrm{~m}$, respectively at VES 22. The second geoelectric layer is weathered layer. The layer with resistivity varies from 19 to $90 \Omega \mathrm{m}$ while the layer thickness varies from 2.5 to $21.3 \mathrm{~m}$. The weathered layer is composed of clay. The fresh basement resistivity varies from $122 \Omega \mathrm{m}$ to infinity and the depth to basement varies from 3.2 to $20.2 \mathrm{~m}$. The overburden is shallow especially at VES 19 and generally thick and thickest under VES 17 . The basement relief is uneven. The basement depression is noticed at VES 17 and 23. The failed segment of road pavement at southwestern flank on which VES 16 to VES 20 surveys were carried out is composed of thin topsoil with a mean resistivity and thickness of $152 \Omega \mathrm{m}$ and $1.0 \mathrm{~m}$, respectively. The weathered layer with a mean resistivity and thickness of $54 \Omega \mathrm{m}$ and $9.3 \mathrm{~m}$ which is typically composed of clay and account to the failure of the road pavement segment. The basement depression at VES 17 could also be another factors responsible for the failure. The stable segment of the road pavement at Northeastern flank on which VES 21 to VES 25 data were acquired is composed of thin topsoil with resistivity and thickness of $181 \Omega \mathrm{m}$ and $1.1 \mathrm{~m}$, respectively which indicates sand layer and account for stability of the road pavement segment. Laterite beneath topsoil has resistivity and thickness of $224 \Omega \mathrm{m}$ and $1.9 \mathrm{~m}$ at VES 22, this also account for the stability. This segment may likely fail in future due to basement depression, that is thick low resistive weathered layer beneath VES 23.

Figure 9 shows the geoelectric section relating VES 26 to VES 30 along SW-NE direction. Four lithological layers comprising of topsoil, weathered layer, partially weathered/ fractured basement and fresh basement were delineated. The topsoil resistivity varies from 83 to $338 \Omega \mathrm{m}$ while the layer thickness varies from 0.6 to $1.1 \mathrm{~m}$. The topsoil is composed of clay/lateritic sand. The weathered layer resistivity varies from 102 to $339 \Omega \mathrm{m}$ and layer thickness varies from 5.8 to $16.5 \mathrm{~m}$. The weathered layer is typically composed of sandy clay/sand/lateritic sand. The third layer is partially weathered/fractured basement. The layer resistivity and thickness are $19 \Omega \mathrm{m}$ and $30.5 \mathrm{~m}$, respectively at VES 29 which may account for the failure of the segment road pavement. The fresh basement 


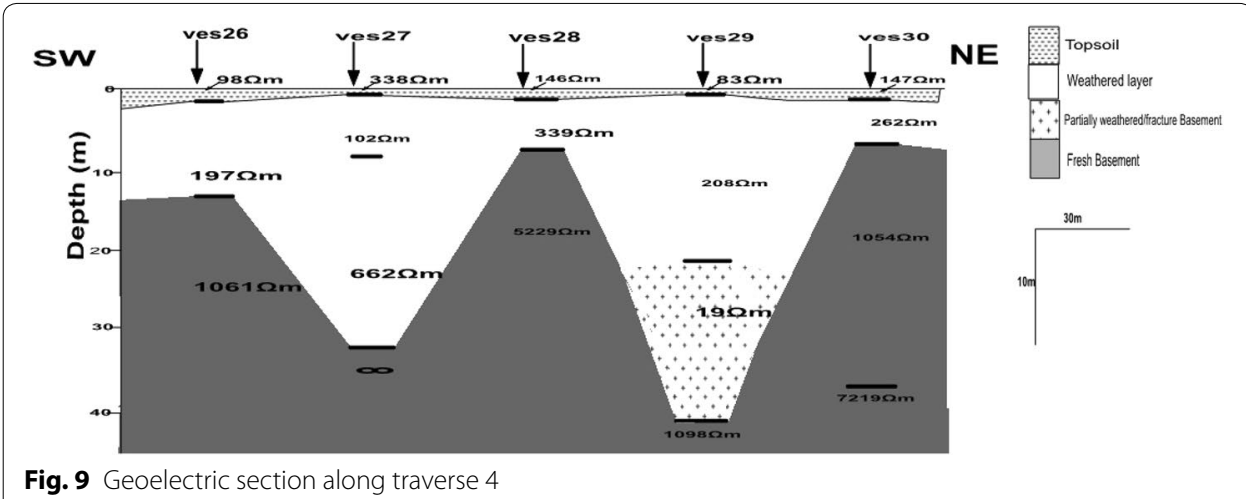

Fig. 9 Geoelectric section along traverse 4

resistivity varies from $662 \Omega \mathrm{m}$ to infinity and the depth to basement varies from 7.2 to $41.7 \mathrm{~m}$. The overburden is thin at VES 28 and VES 30, and thick at VES 27 and VES 29. The basement relief is uneven and basement depression is noticed at VES 27 and VES 29. The failed segment of the road pavement on which VES 26 and VES 29 data were acquired, is composed of thin topsoil with mean resistivity and thickness of $91 \Omega \mathrm{m}$ and $0.9 \mathrm{~m}$ which indicates clay material and possibly account for failure of the road pavement segment. The weathered layer with a mean resistivity and thickness of $203 \Omega \mathrm{m}$ and $14.2 \mathrm{~m}$ indicates lateritic sand which is capable to withstand wheel loads. The VES 29 survey also delineated partially weathered/fractured, basement with resistivity and thickness of $19 \Omega \mathrm{m}$ and $24.6 \mathrm{~m}$, respectively which may have also contributed to the failed segment of the road pavement.

The stable segment of the road pavement on which VES 27, VES 28 and VES 30 data were acquired, is composed of thin high resistive topsoil with a mean resistivity and thickness of $210 \Omega \mathrm{m}$ and $1.1 \mathrm{~m}$, respectively which indicates lateritic sand and account for the stability of the road pavement segment. The weathered layer has a mean resistivity and thickness of $234 \Omega \mathrm{m}$ and $11.0 \mathrm{~m}$ which indicates lateritic sand composition and this further account for the stability of the segment.

\section{Dipole-dipole profiles}

The 2-D resistivity structure obtained from the inversion of the dipole-dipole along Traverse 1-4 are shown in Figs. 10, 11, 12, 13. The 2-D resistivity structure revealed three lithological layers; thin topsoil (purple colour band), weathered layer (purple and red colour band) and the fresh basement rock (orange, greenish yellow, green and blue colour band). It also revealed fracture/fault zone as purple colour band between two high resistive orange/green colour bands. The topsoil layer generally subsumed into the weathered layer in many places due to its thickness.

Figure 10 shows the 2-D resistivity structure along SW-NE direction. The profile revealed generally low resistivity values $(<100 \Omega \mathrm{m})$ at many station points beyond a depth of $5 \mathrm{~m}$. The low resistivity values characterised by purple colour band indicate the presence of clay enriched water absorbing substratum. Station 2 to station 9 and station 21 to station 31 showing weathered substratum and fresh basement at average depth of $7 \mathrm{~m}$. 


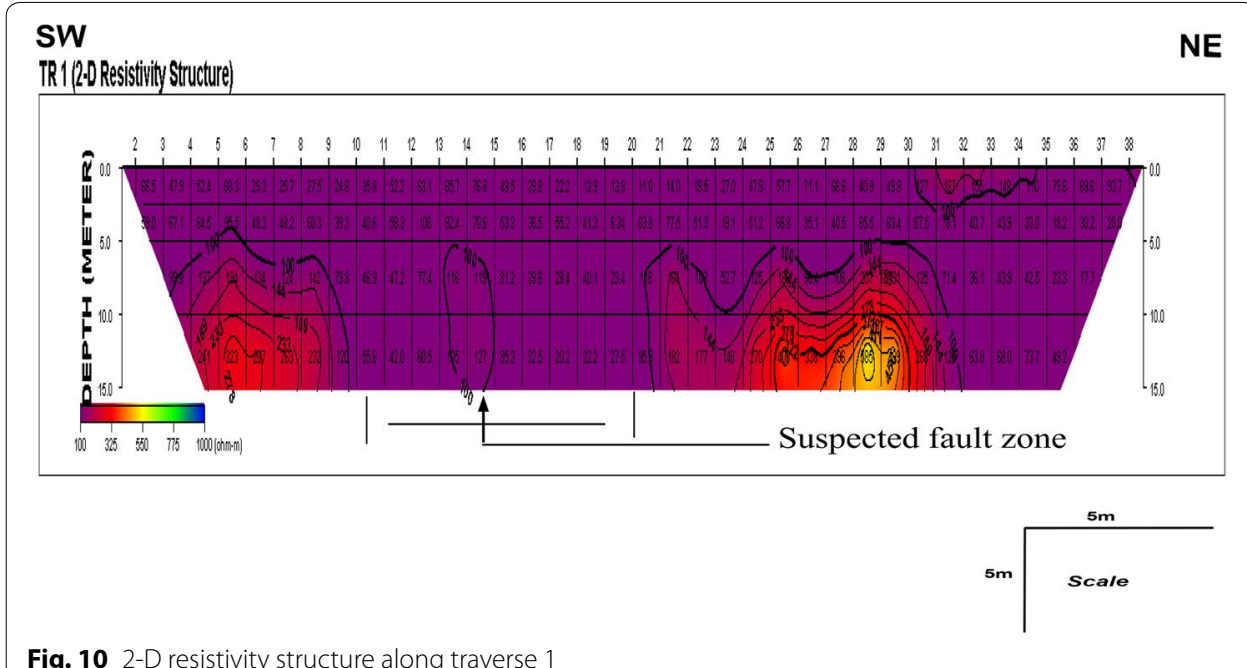

Fig. 10 2-D resistivity structure along traverse 1

\section{SW}

Traverse 2 (2-D Resistivity Structure)

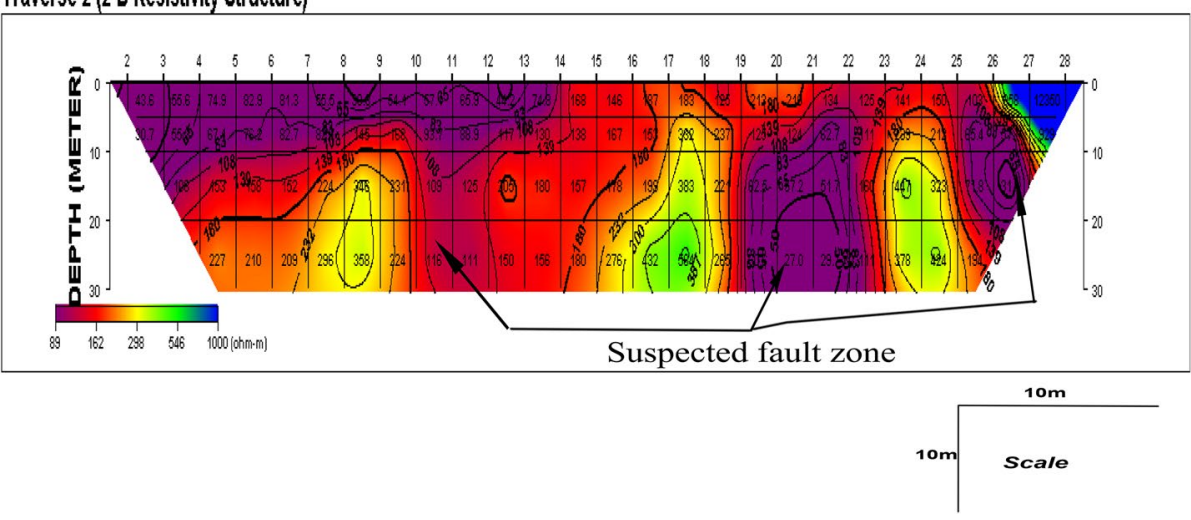

Fig. 11 2-D resistivity structure along traverse 2

transverse 3(2-D Resistivity Structure)

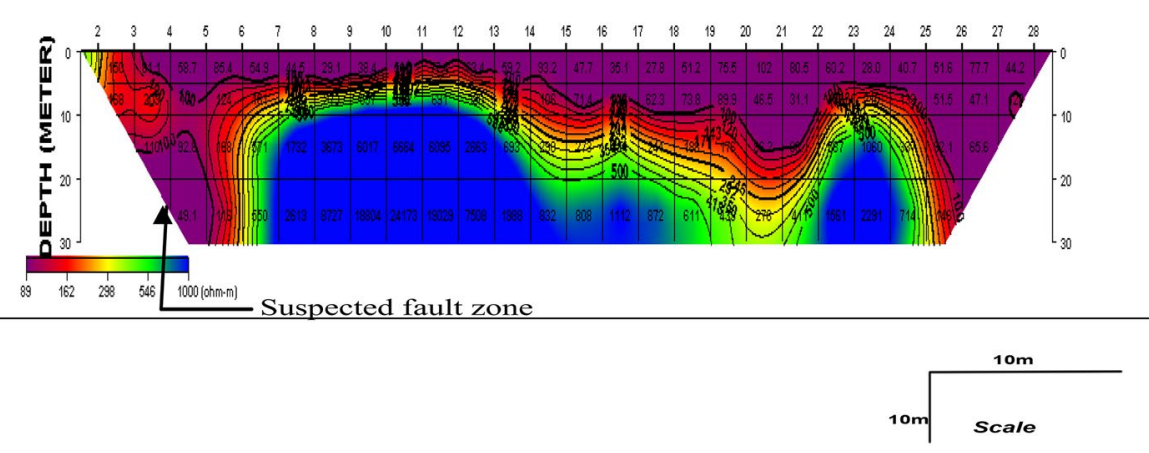

Fig. 12 2-D resistivity structure along traverse 3 


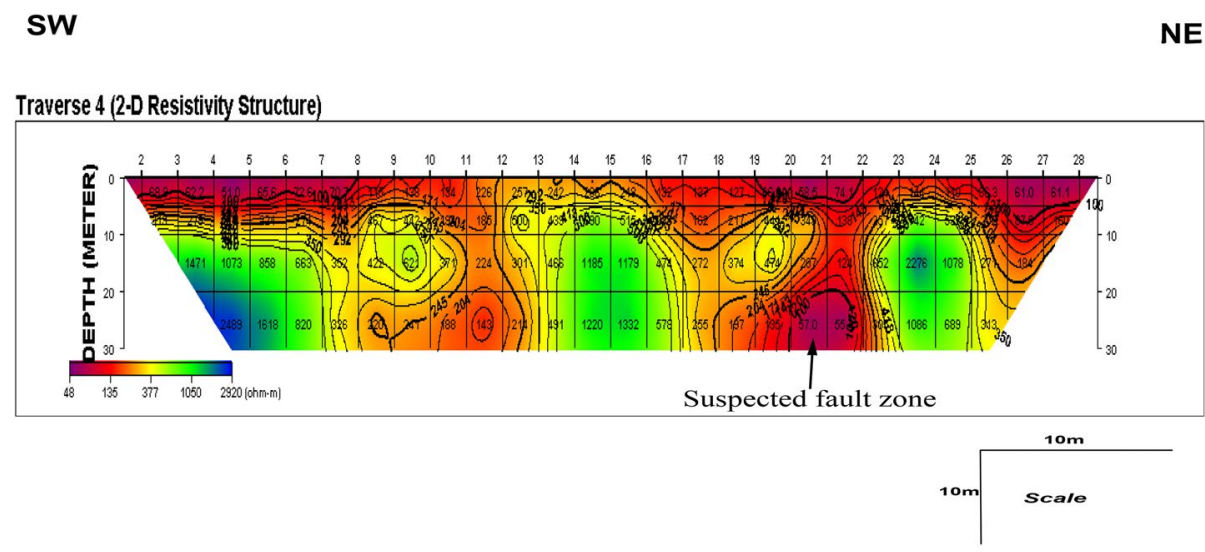

Fig. 13 2-D resistivity structure along traverse 4

The stable segment in the southwestern flank starts from station 1 to station 9 (surface distance expression of 5 to $45 \mathrm{~m}$ ). This segment is characterised by low resistivity $(<100 \Omega \mathrm{m})$ substratum with depth extent of $5 \mathrm{~m}$. This is indicative of clay materials which is not suitable for road pavement. The overburden depth is $10 \mathrm{~m}$ and the resistivity of basement (orange/yellow colour band) ranges from 232 to $323 \Omega \mathrm{m}$. The stability of this road pavement segment may be due to recent rehabilitation exercise, but the segment is very liable to fail in future due to the presence of thick low resistivity clay enriched in water. Station 25-34 are along the stable segment in the northeastern flank also shows the same characteristics as the stable segment in the Southwestern flank. Its overburden depth is $10 \mathrm{~m}$ and the resistivity of basement ranges from 290 to $585 \Omega \mathrm{m}$. This segment is stable presently but also liable to fail in future, because of the presence of thick low resistivity clay enriched in water. The failed segment starts from station 9-25 (distance of $45 \mathrm{~m}$ to $130 \mathrm{~m}$ ) and shows no fresh basement but decreasingly low resistivity features with significant depth extent $>15 \mathrm{~m}$ were observed. This could be suggestive of typical of linear features (suspected fault zone), aquiferous zone or buried channel which may have accounted for the extremely bad condition of this failed segment and may likely affect the neighbouring stable segment.

Figure 11 shows the 2-D resistivity structure along SW-NE direction. The 2-D resistivity structure delineated three lithological layers namely; topsoil marked by purple colour except few points with green and blue, weathered layer marked by orange and fresh basement marked by orange/yellowish green/blue. The topsoil is generally thin and subsumed into weathered layer in many places due to its characterisation by sand materials between station 14-26 and laterite (intrusion) between station 26-30 at the northeastern flank but the topsoil is composed of clay in other stations at the southwestern flank. Stations 1-14 is characterised by purple colour bands shows a low resistivity values $(<100 \Omega \mathrm{m})$ with average depth of about $12 \mathrm{~m}$. This indicates a typical clay. It however identifies isolated near vertical/vertical low resistivity features having depth extent $>30 \mathrm{~m}$ typical of faults/fractures/buried stream channels/aquiferous zones at stations 10-12; stations 19-25 and stations 25-26.

The failed segment of the road pavement in the southwestern flank start from stations $1-14$. It is characterised with low resistivity $<100 \Omega \mathrm{m}$ substratum and depth range of 
$0-10 \mathrm{~m}$. This resistivity is typical of clay composition which may account for the failure of the segment. Between stations 10-12 (surface distance expression of 30-36 m), there exists miniature vertical discontinuity that is typical of linear structure. The suspected linear structure of significant depth extent $(>10 \mathrm{~m})$ could be diagnostic of a suspected fault/fracture zone. The suspected fault zone falls within the extremely failed segment of the road. The 2-D geoelectric section at the southwestern flank at VES 7 confirmed the existence of suspected fault zone.

The stable segment of the road pavement along SW-NE direction starts from station 14 to station 30 and is generally characterised by high resistive substratum (clayey sand/ sand/lateritic sand with resistivity ranging from 125 to $276 \Omega \mathrm{m}$ ) from the topsoil, but stations 26-30 show extremely high resistivity ranging from 729 to $12,350 \Omega \mathrm{m}$ (outcropping basement). This account for stability of this segment. Beneath this segment, the station 19-22 and station 25-27 with depth extent of $>5 \mathrm{~m}$ and $>1 \mathrm{~m}$, respectively, show decreasingly vertical low resistivity values beyond $30 \mathrm{~m}$ depth. This indicates clay with high moisture content which is suggestive of suspected fault zone, aquiferous zone or buried channel due to absence of drainage system. These stations may likely fail in future. The 2-D geoelectric section along traverse 2 confirms these stations (stations 19-23 and stations 25-26) at VES 11, VES 12 and VES 14 as basement depression composed of decreasingly low resistivity substratum (clay).

Figure 12 shows the 2-D resistivity structure along SW-NE direction. The 2-D resistivity structure shows generally low resistivity value from the topsoil with thin overburden at stations $6-13$ but thicker at station 13 to station 22 . However, it identifies isolated near vertical low resistivity features having depth $>30 \mathrm{~m}$ which indicates typical of fault/ fracture zones at stations 3-6 (surface distance of 30-60 m).

The failed segment of the road pavement in the southwestern flank starts from stations 1-15 has low resistivity value of $<100 \Omega \mathrm{m}$ which is characterised by clay and basically account for the failure of this segment. Stations 2-6 shows vertical discontinuity that is typical of linear structure such as fault zones. The suspected linear structure is of significant depth $(>30 \mathrm{~m}$ ) which may have been responsible to extremely failed segment of the road pavement. The stable segment toward northeastern flank starts from stations $14-30$. It is characterised by low resistivity $(<100 \mathrm{~m})$ substratum which indicates clay composition with depth extent of $15 \mathrm{~m}$. The depth to basement varies from 9 to $20 \mathrm{~m}$. This segment of road in the northeastern flank show no sign of failure or reconstruction. Despite the low resistivity substratum beneath the road pavement. This may be that, good construction material were used. The basement bedrock relief of 2-D geoelectric section confirms the 2-D resistivity structure.

Figure 13 shows the 2-D resistivity structure along SW-NE direction. The 2-D resistivity structure shows that the topsoil subsumes into the weathered layer and low resistivity values $(<100 \Omega \mathrm{m})$ between stations $2-8$; stations $19-22$ and stations $26-30$ are indicative of clay composition. The weathered layer generally has a relatively high resistivity values (120-299 $\Omega \mathrm{m})$ in green coloration and is characterised by sand/lateritic sand. Stations $8-10$ and stations $18-20$ both at the same depth $(6 \mathrm{~m})$ could be as a result of the decomposition that was left after weathering. The fresh basement is marked by yellowish green/blue colour band. The high resistivity of the weathered layer substratum is due to the nature of rock type (pegmatite) in the area. 


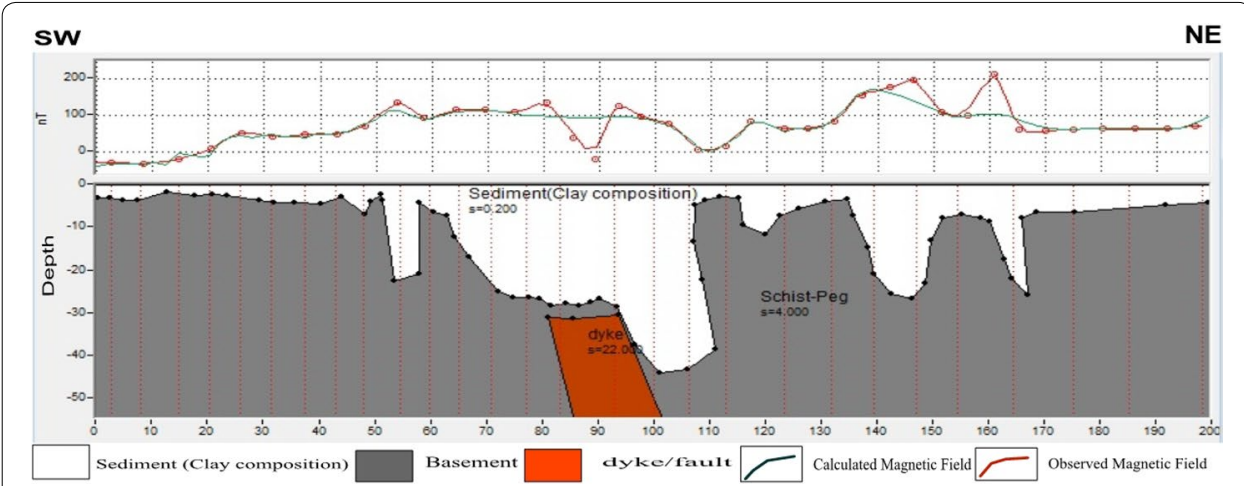

Fig. 14 Model of magnetic profile along traverse 1

The failed segment of the road pavement in southwestern flank at stations 1-8 (10$80 \mathrm{~m})$ has low resistivity $(<70 \Omega \mathrm{m})$ and it is characterised by clay with depth extent of $<3 \mathrm{~m}$, which account to the failure of this segment. Stations 19-22 and station 25 correspond to another failed segments in the northeastern flank and are also characterised by low resistivity $(<100 \mathrm{~m})$ substratum with depth extent of $<8 \mathrm{~m}$. The subsurface beneath stations $19-22$ has high resistivity ranging from 120 to $246 \Omega \mathrm{m}$ and depth extent of $>5 \mathrm{~m}$ but it has low resistivity value $<57 \Omega \mathrm{m}$ with depth extent of $>20 \mathrm{~m}$, which could be diagnostic as suspected fault zone or aquiferous zone. This may also contribute to the failure of the segment. The stable segments, stations 8-19 and stations $22-25$ are characterised by high resistivity varying from $115-292 \Omega \mathrm{m}$ underlying the road pavement which indicate typical sandy clay, sand, lateritic sand and hence responsible for the stability of these segments. Moreover, the closeness of the basement rock (at depth of $5 \mathrm{~m}$ ) to the surface at stations $13-16$ and stations $22-25$ also account to the stability of these segments.

\section{Magnetic models interpretation}

2.5 D magnetic modeled profiles of the subsurface are generated from the magnetic data using the WINGLINK modeling software indicating variation in magnetic susceptibility of the rock units in the area. The magnetic anomalies observed in the study area were assumed to have resulted from the basement as well as magnetic materials contained within the fractured/faulted zones relative to the fresh massive bedrock. The models shows very good fit between the observed and calculated magnetic profiles.

The magnetic profile (Fig. 14) was modeled using open body dividing into two parts: the Sediment and the Basement. The sediment is composed of clay composition with low magnetic susceptibility of 0.0002 SI unit Clark and Emerson [7]. The sediment thickness is thin along SW flank and at the NE flank while it is the thickest (depth of $45 \mathrm{~m}$ ) at the mid-distance between the SW and the NE flank. The thin sediment (shallow basement) between station 1-50 m at the SW flank and between station 120-200 m at the NE flank could be responsible to the present stability of the segments. The basement (Schist-Pegmatitised) has low magnetic susceptibility of 0.004 SI unit and its topography is uneven. The Model shows deep basement depression and basement structure (such as dyke, suspected fracture, fault or weak zone) between 50 and $110 \mathrm{~m}$ at mid-distance 


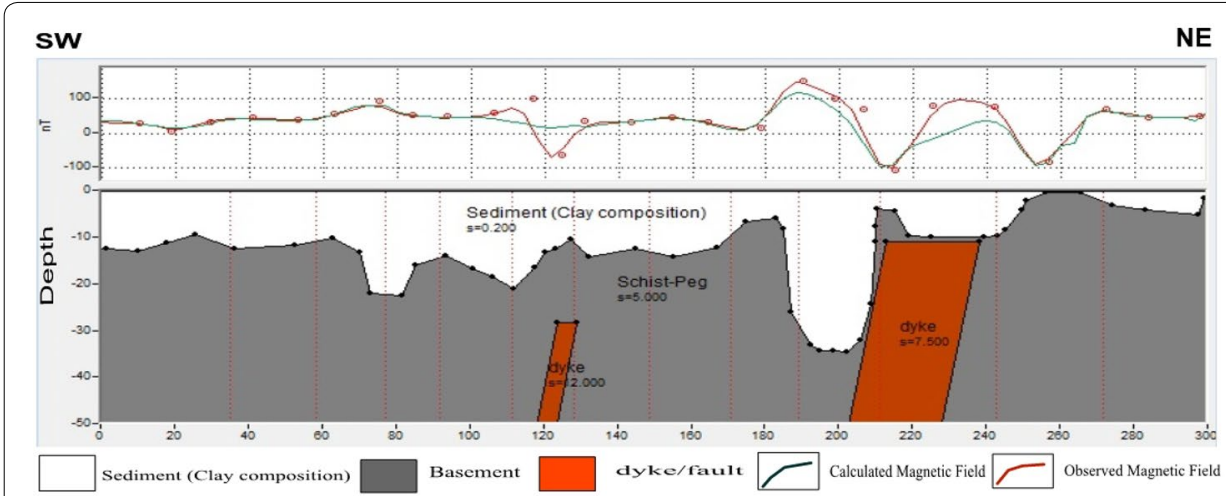

Fig. 15 Model of magnetic profile along traverse 2

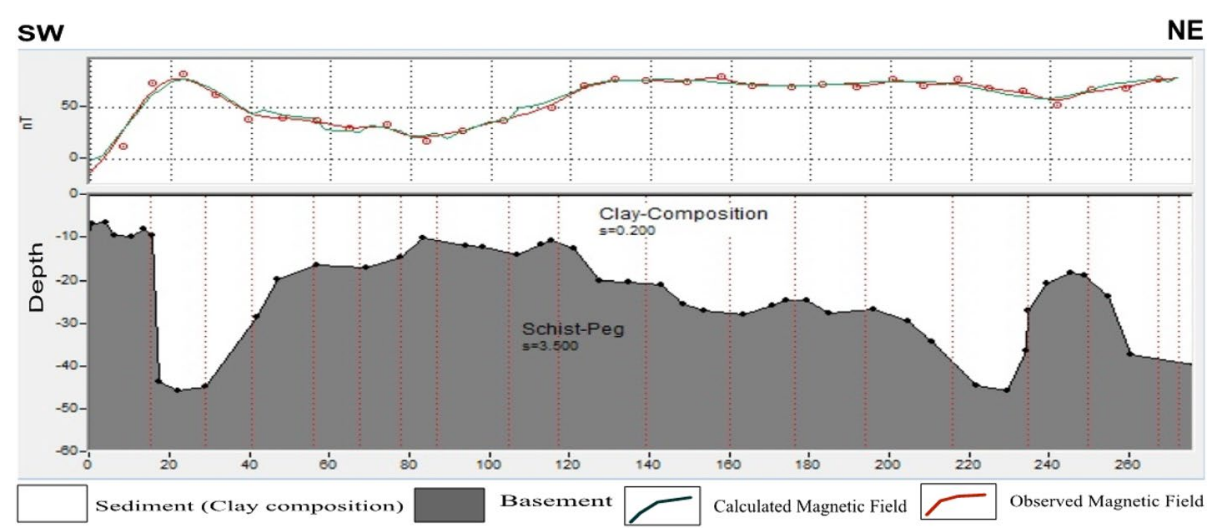

Fig. 16 Model of magnetic profile along traverse 3

between SW and NE which the Profile shows as W shape (thick dyke). The suspected basement structures disposition account for the failure of the road pavement segment.

The magnetic profile (Fig. 15) was modeled using open body dividing into two parts: the Sediment and the Basement. The sediment is composed of clay composition with low magnetic susceptibility of $0.0002 \mathrm{SI}$ unit. The sediment thickness is moderately thick with average thickness of about $10 \mathrm{~m}$ and thinnest at the NE flank (outcropping). The outcrop may likely account for the present stability of the segment of the road pavement at NE flank. The basement (Schist-Pegmatitised) has a low magnetic susceptibility of 0.005 SI unit and its topography is unevenly distributed. The model shows basement depression at distance between 180 and $200 \mathrm{~m}$ and basement structure (such like dyke, fracture/fault or weak zones) at distance between 110 and $130 \mathrm{~m}$ along the SW flank which the profile shows as V shape (thin dyke structure) and at stations between 200 and $230 \mathrm{~m}$ along the NE flank, the profile shows W shape (thick dyke structure). The basement structures along SW flank may have been responsible for the failure of the pavement above it. At NE flank, the basement depression and structures may contribute to the failure of the segment above it in future, though it is presently stable.

The magnetic model (Fig. 16) revealed that the sediment is composed of clay composition with low magnetic susceptibility of 0.0002 SI unit. The sediment thickness is 


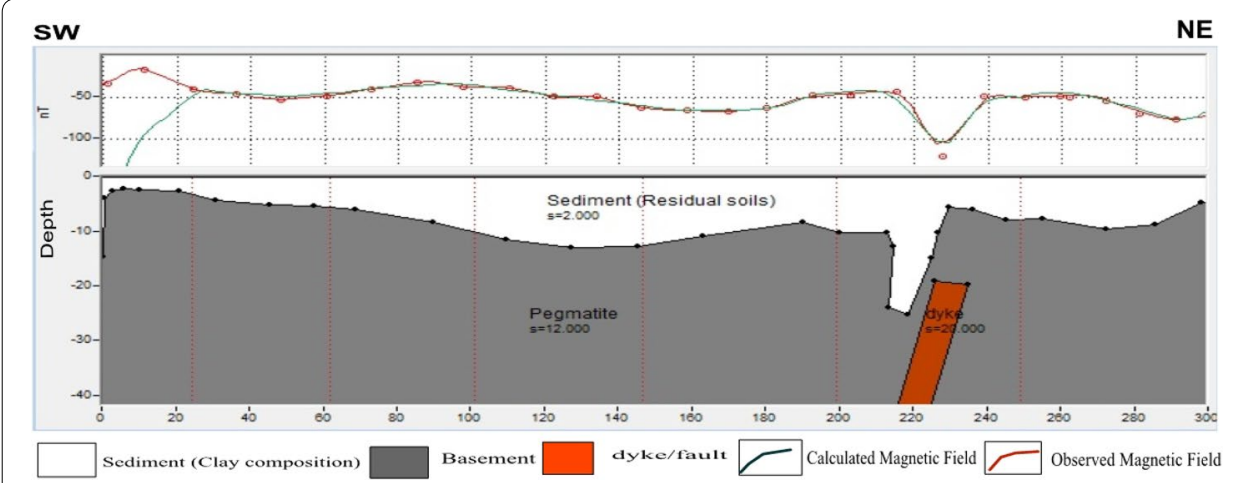

Fig. 17 Model of magnetic profile along traverse 4

moderately thick between station distance 50-140 m with average thickness of about $15 \mathrm{~m}$ and thickest at distance 20 and $220 \mathrm{~m}$ with depth extent of about $45 \mathrm{~m}$. The basement (Schist-Pegmatitised) has a low magnetic susceptibility of 0.0035 SI unit. The basement topography is unevenly distributed. Along the SW flank, at distance between 20-40 m shows basement depression which may have contributed to the failure of the pavement above it and also the depression at the NE flank may likely cause the stable segment to fail in future.

The magnetic model along traverse 4 (Fig. 17) revealed that the sediment is composed of residual soil (laterite) with low magnetic susceptibility of 0.002 SI unit. The sediment thickness is thin along SW flank while at the mid-distance between SW and NE and the NE flank, the sediment is thick with an average thickness of about $7 \mathrm{~m}$. The basement (Pegmatite) has low magnetic susceptibility of 0.012 SI unit and its topography is unevenly distributed. Along the NE flank, at the distance between 210 and $230 \mathrm{~m}$, the model shows basement depression and structures which may indicate linear geological features such as dyke, fracture/fault, shear or weak zones. The profile showed V shape (thin dyke structure) at the point. This may actually be the cause of the failure along the segment.

\section{Correlation of results}

The results obtained from the integrated geophysical investigation (electrical resistivity and magnetic methods) are correlated to deduce the causes of recurring road pavement failure. The correlation of results involve geoelectric sections, 2-D resistivity images and magnet models which were grouped into four panels as shown in Figs. 18, 19, 20, 21. The first panel is the segments of road pavement, the second panel is the geoelectric section, the third panel is the 2-D resistivity structure and the fourth panel is magnetic modeled profile.

Figure 18 shows the correlation of electrical resistivity and magnetic results across both stable and failed segments of the road pavement. The stable segment at SW flank is characterized by relatively high resistivity topsoil in the depth range 0-2 $\mathrm{m}$ with resistivity value of $321 \Omega \mathrm{m}$ and the subsoil layer is composed of clay between distance $0-40 \mathrm{~m}$ as observed in the geoelectric section. The relative flat magnetic profile and 2-D resistivity structure along this segment are devoid of linear feature such as fracture/fault zone or lithological contact are indication of near homogeneous 


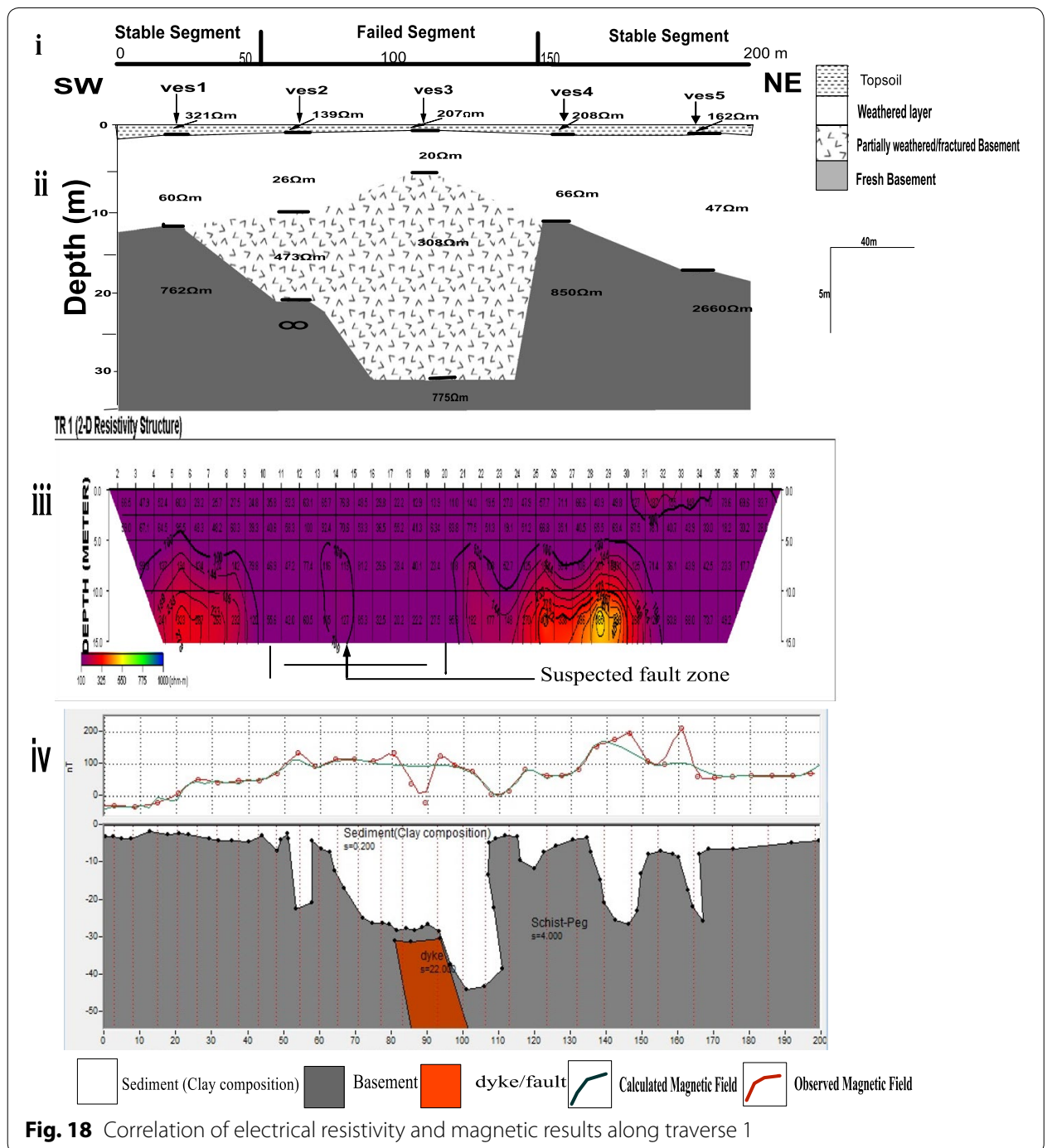

subsurface sequence. The failed segment between the distance $40-125 \mathrm{~m}$ is characterised by low resistivity thin topsoil and the subsoil (weathered layer) in the depth range $0-11 \mathrm{~m}$ and are composed of clayey materials as observed at the geoelectric section. The sediment composed of clay shown in 2-D magnetic model and 2-D resistivity structure characterised by blue colour band $(<100 \Omega \mathrm{m})$ correlate with nature of sub-soil (clay) in the geoelectric section which is not suitable for road pavement subgrade materials. The 2-D resistivity structure shows no fresh basement even at depth extent of $>15 \mathrm{~m}$. Within the basement observed in geoelectric section, 2-D magnetic model and in the 2-D resistivity are identified subsurface linear feature zones beneath the segment at VES 2 and VES 3 with thick weathering depth typical of fractured/ fault, aquiferous, buried stream channel or fissure zones within the basement rocks. The identified linear features have significant depth extent $(>5 \mathrm{~m})$ which may indicate geological features such as fractures/faults.

The stable segment of the road pavement at NE flank is characterized by relatively high resistivity topsoil in the depth range $0-2 \mathrm{~m}$ with mean resistivity values of $185 \Omega \mathrm{m}$. The 


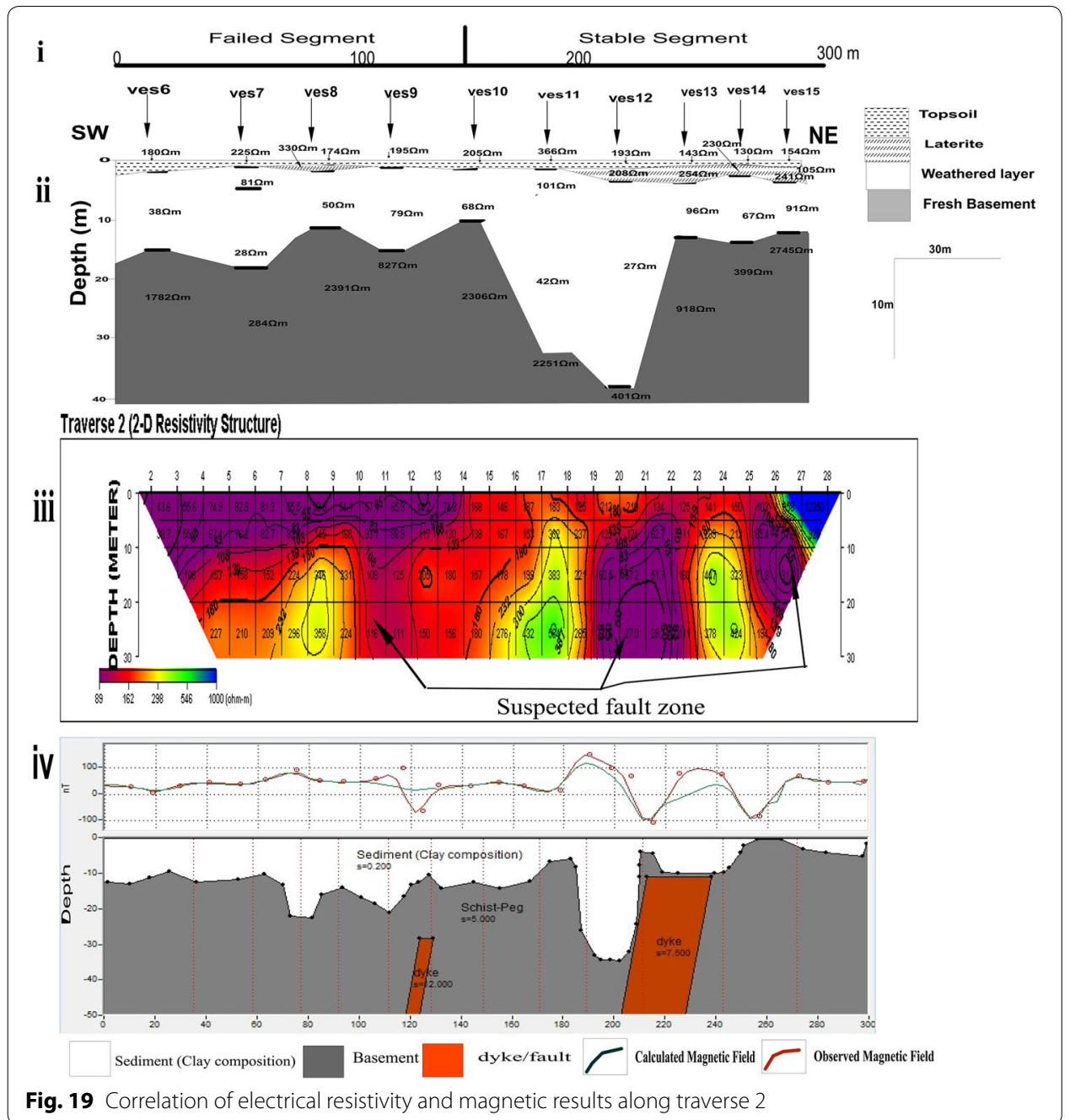

subsoil (weathered layer) is composed of clay in the depth range $0-9 \mathrm{~m}$ as observed in the geoelectric section between distance 130-155 m which correlates with the 2-D resistivity structure with resistivity value less than $100 \Omega \mathrm{m}$ at nearly the same depth. The distance between 155 and $200 \mathrm{~m}$ observed in the 2-D magnetic model shows a relatively magnetic quietness correlates with 2-D resistivity structure which imply the segment is devoid of linear features. The presence of low resistive substratum (clay) precipitation may cause failure to this segment in future. The 2-D magnetic model showed a moderately shallow basement in this segment which may be responsible to the present stability of the road pavement, but the basement depressions may cause failure of this segment in future.

Figure 19 shows the correlation of electrical resistivity and magnetic results in both failed and stable segments of the road pavement. The failed segment, between the distance $0-150 \mathrm{~m}$, the topsoil is thin with moderate resistive value. The subsoil is thick with average depth extent of about $15 \mathrm{~m}$ which is composed of typical clay with resistivity varying from 28 to $81 \Omega \mathrm{m}$ observed in the geoelectric section. The sediment composed of clay shown in 2-D magnetic model and 2-D resistivity structure characterised by purple colour band $(<100 \Omega \mathrm{m})$ at nearly the same depth of $12 \mathrm{~m}$ correlate with nature of 


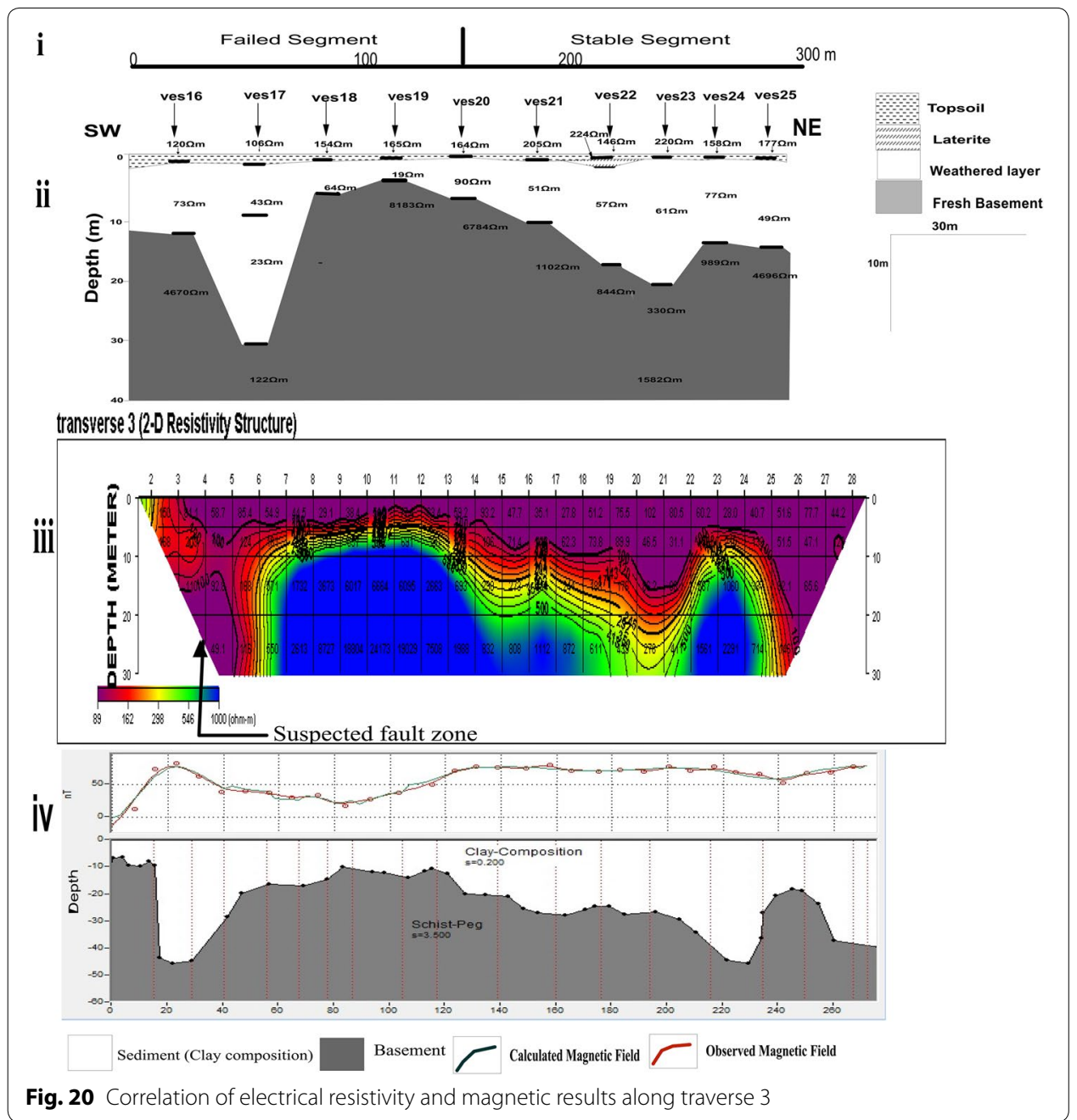

sub-soil (clay) in the geoelectric section which is not suitable for road pavement subgrade materials. The 2-D magnetic model and 2-D resistivity structure delineated suspected basement structures (dyke, fracture/fault, weak or shear zones) at distance between 100 and $130 \mathrm{~m}$ which is revealed in the geoelectric section at the same distance. The road failure in this segment may have been caused by the nature of soil sediment (clay) and the suspected near or basement structures.

The stable segment of the road pavement at the NE flank, between distance 150$300 \mathrm{~m}$ is characterised by relatively high resistive topsoil in the depth range $0-6 \mathrm{~m}$ with resistivity values greater than $130 \Omega \mathrm{m}$ which is composed of sandy clay, clayey sand and laterite observed in the geoelectric section. The moderately shallow depth to basement and outcrops observed in the 2-D magnetic model and the orange/green/blue coloured band indicating high resistive substratum, especially the blue coloured band at the surface indicating outcrops observed in the 2-D resistivity structure, correlate with high resistive substratum (lateritic layer) in the geoelectric section. These have actually been responsible for the stability of this road segment presently, but the identified precipitate low resistive substratum (clay) and basement depression observed in the geoelectric section and basement structures and depression observed in both 2-D magnetic model and 


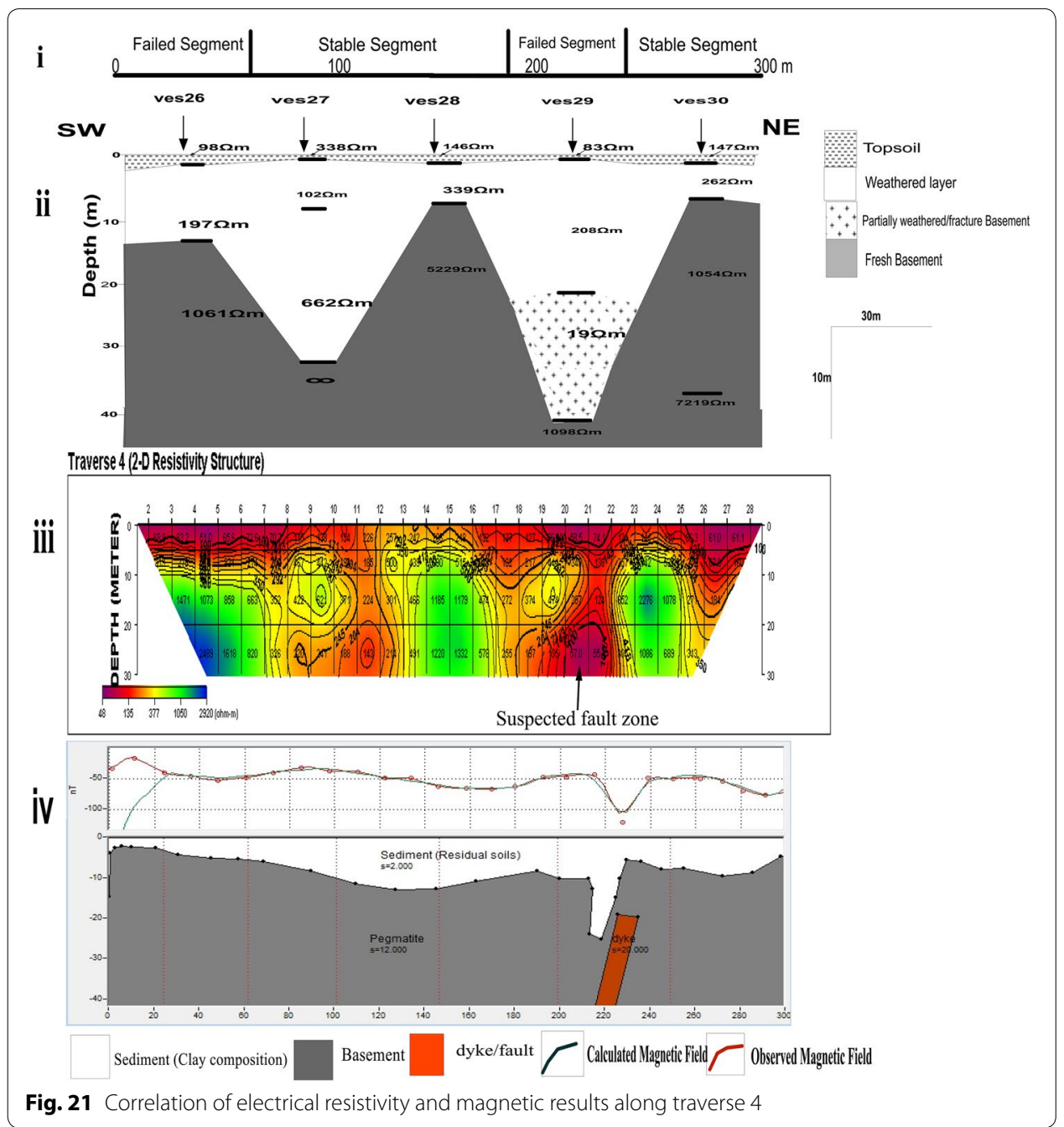

2-D resistivity structure may cause some parts of this segment to fail greatly in a short while.

Figure 20 shows the correlation of electrical resistivity and magnetic results in both failed and stable segments of the road pavement. The failed segment at SW flank between the distance $0-150 \mathrm{~m}$ is characterised by relatively high resistivity topsoil in the depth range $0-1.9 \mathrm{~m}$ with resistivity varying from 106 to $165 \Omega \mathrm{m}$. The subsoil layer composed of low resistive substratum (clay) less than $100 \Omega \mathrm{m}$ in the depth $0-12 \mathrm{~m}$. The basement depression beneath VES 17 with depth of about $32 \mathrm{~m}$ observed in geoelectric section correlates with the basement depression observed in the 2-D magnetic model with depth of $45 \mathrm{~m}$ between distance $20-50 \mathrm{~m}$. The 2-D resistivity structure identifies a near vertical low resistivity features with a depth extent $>30 \mathrm{~m}$ which indicates a typical linear features such as fault/fracture at distance between 20 and $50 \mathrm{~m}$. The nature of soil (clay), suspected linear features and basement depression may have been the factors responsible to the failure of this segment of the road pavement along the traverse. The stable segment of the road pavement is characterised by relatively high resistivity topsoil in the depth range $0-2.5 \mathrm{~m}$ with resistivity values greater than $140 \Omega \mathrm{m}$. The subsoil layer 
is composed of low resistive substratum (clay) less than $100 \Omega \mathrm{m}$ with average thickness of about $17 \mathrm{~m}$ observed in the geoelectric section. The 2-D magnetic model and 2-D resistivity structure delineated the same basement topography with average depth to basement of 35 and $15 \mathrm{~m}$, respectively. The identified basement depression may likely cause failure of this segment in future, but physically this segment appears stable. This may be due to good construction materials that were used during construction of the road pavement.

Figure 21 shows the correlation of electrical resistivity and magnetic results on both the failed and stable segments of the road pavement. The failed segment near the SW flank is characterised by low resistivity topsoil in the depth range $0-1.8 \mathrm{~m}$ with resistivity value less than $100 \Omega \mathrm{m}$ (clay) observed in the geoelectric section which correlates with low resistivity $(<100 \Omega \mathrm{m})$ topsoil in the depth range $0-2 \mathrm{~m}$ between station distance 0-60 m observed in the 2-D resistivity structure. The failed segment, near the NE flank is characterised by low resistivity $(<100 \Omega \mathrm{m})$ thin topsoil in the depth range $0-0.9 \mathrm{~m}$ observed in the geoelectric section which correlates with the low resistivity (purple colour band) in the depth range $0-1.2 \mathrm{~m}$ observed on 2-D resistivity structure between station distance 190-220 m. The fractured basement beneath VES 29 in the geoelectric section and the suspected fault zone observed in 2-D resistivity structure correlate with the suspected dyke, fracture/fault or weak zone observed in the 2-D magnetic model at station distance between 190 and $220 \mathrm{~m}$.

The stable segment of the road pavement at station distance between 80 and $190 \mathrm{~m}$ and $230-300 \mathrm{~m}$ is characterised by relatively high resistivity $(>147 \Omega \mathrm{m}$, lateritic formation) topsoil in the depth range $0-1.7 \mathrm{~m}$. The subsoil layer composes of clayey sand and lateritic formation with resistivity values varying from 102 to $662 \Omega \mathrm{m}$ observed in the geoelectric section. The sediment is made of residual soil (laterite) observed in 2-D magnetic model and the high resistive substratum (laterite) characterized by green/greenish yellow/blue colour band in the 2-D resistivity structure correlate with the lateritic formation observed in the geoelectric section. The lateritic formation account for the stability of the road pavement segment and it is very suitable for road pavement sub-grade materials.

\section{Engineering subsurface evaluation of the study area}

The sub-grade soil beneath a stable highway pavement is expected to possess sufficient strength to support the structure or wheel load imposed on it. It must not swell or shrink excessively and must have proper permeability and drainage characteristics [16].

The failed segments in the study area are underlain by Schist-pegmatitised (Fig. 2). The rock type is susceptible to weathering and can weather into clay materials (sandy clay and clayey sand). The topsoil of the segments are clayey with sand/lateritic sand with mean resistivity value $185 \Omega \mathrm{m}$ and the mean thickness of $0.7 \mathrm{~m}$. The relatively high resistivity values of the layer may be due to the presence of left over or fragment road materials on the road (sandstone/gravel) after rehabilitation. The sub-grade soil beneath the subsurface is generally clayey with resistivity less than $100 \Omega \mathrm{m}$ and its layer thickness varies from 0.6 to $39.4 \mathrm{~m}$. The linear features suspected to be dykes, faults/fractured zones, buried stream channel were also delineated. 
The stable segments along the traverses 1, 2 and 3 also have the same geological rock types as in the failed segment. The stable segment along traverse 2 is due to the presence of laterite which may have formed through the oxidation of clay $\left(\mathrm{Fe}^{3+}\right.$ to $\left.\mathrm{Fe}^{2+}\right)$ exposed to the surface, becomes hard solid and outcrops in the segment. Physically, some segments are very stable due to the use of good construction materials. The stable segments along Traverse 4 is underlain by Pegmatite (Fig. 2a). The rock type is very strong, which weathers into residual soil (gravel/laterite). The stable segment as shown in the geoelectric section, 2-D resistivity structure and magnetic modeled profile show no significant subsurface linear features. The topsoil is highly resistive and sub-grade soil is lateritic with significant thickness of $13 \mathrm{~m}$ which is enough to withstand the imposed traffic load stress.

\section{Conclusion}

In this study, integrated geophysical methods have been used to investigate the causes of incessant highway pavement failure along segments of Ibadan-Ife highway around Ipetumodu in the basement complex terrain southwestern Nigeria.

It can be concluded that the possible causes of incessant highway pavement failure along the studied highway are:

i. Thick and low resistive substratum $(<100 \Omega \mathrm{m}$, clayey sub-grade soil). The soil type absorbs water, swells and collapses under imposed traffic load stress and thereby leading to road pavement failure.

ii. The suspected near-surface linear features such as fractures, fault or lithological contacts which act as zones of weakness that enhances the accumulation of water leading to pavements failure.

iii. Poor drainage of runoff from adjacent topographic highs at the toe of road pavement leading to its ponding observed along traverse 3.

Authors' contributions

$\mathrm{Cl}$ the project researcher who did the write-up, carried out acquisition, processing and interpretation of data. EA and $\mathrm{MO}$ the project advisers who supervised and did proof-feeding of results and write-up. AA, AS and EO the project assistance who assisted in data acquisition and some processing. All authors read and approved the final manuscript.

\section{Author details}

${ }^{1}$ Department of Physics and Engineering Physics, Obafemi Awolowo University, Ile-Ife, Nigeria. ${ }^{2}$ Department of Physics, University of Medical Science, Ondo, Nigeria. ${ }^{3}$ Department of Physical and Mathematical Science, Afe Babalola University, Ado-Ekiti, Nigeria.

Competing interest

The authors declare that they have no competing interests.

Ethics approval and consent to participate

Not applicable.

\section{Publisher's Note}

Springer Nature remains neutral with regard to jurisdictional claims in published maps and institutional affiliations.

Received: 25 July 2017 Accepted: 11 May 2018

Published online: 23 May 2018

References

1. Adeleye AO (2005) Geotechnical investigation of sub-grade soil along sections of Ibadan-Ife highway unpublished M.Sc. project, Obafemi Awolowo University, Ile-lfe, p 181 
2. Adenika Cl (2016) Geophysical investigation of the failed-portions of 58-61 km of Ibadan-Ife road, Southwestern Nigeria (Unpublished M.Sc. Thesis), Department of Physics, Obafemi Awolowo University, lle-lfe

3. Aigbedion I (2007) Geophysical investigation of road failure using electromagnetic profiles along Opoji, Uwenlenbo and Illeh in Ekpoma-Nigeria. Middle East J Sci Res 2(3-4):111-115

4. Ajayi LA (1987) Thought on road failure in Nigeria. Niger Eng 22(1):10-17

5. Balogun OY (2000) Senior secondary atlas, 2nd edn. Longman Nigeria PIc, Lagos Nigeria

6. Carter JD (1965) The geological map of Ife-llesha area. Geological Survey of Nigeria, Nigeria

7. Clark, Ermerson (1991). Magnetic susceptibilities of rocks and minerals, Ahrens. American Geophysical Union. Appendix, pp 96-121

8. Dippro for Window (2000) Dippro ${ }^{\mathrm{TM}}$ Version 4.0. Processing and interpretation software for Dipole-dipole electrical resistivity data. KIAM, Daejon

9. Federal Survey (1978) Atlas of the Federal Republic of Nigeria, 1st edn. Federal Surveys, Lagos, p 136

10. Iloeje NP (1981) A new geography of Nigeria (New Revised Edition). Longman Nig. Ltd., Lagos, p 201

11. Kurtenacker KS (1934) Some practical application of resistivity measurement to highway problem. Trans Am Inst Min Metall Eng 110:49-59

12. Mesida EA (1981) Laterites on the highways—understanding soil behaviour. West African Technical Review. pp $112-118$

13. Momah LO, Akintorinwa O, Olorunfemi MO (2008) Geophysical investigation of highway failure. A case study from the basement complex of southwest Nigeria. J Appl Sci Res 4(6):637-648

14. More RW (1952) Geophysical methods adapted to highway engineering problems. Geophysics 17:505

15. Obaje NG (2009) Geology and mineral resources of Nigeria. Springer, Dordrecht

16. Oladapo MI (1998) Geophysical and geotechnical investigation of road failure in the basement complex areas of Southwestern Nigeria (unpublished M.Sc. thesis), Department of Applied Geophysics, Federal University of Technology, Akure

17. Olorunfemi MO, Fatoba JO, Ademilua LO (2005) Integrated VLF-electromagnetic and electrical resistivity survey for groundwater in a crystalline basement complex terrain of southwestern Nigeria. Glob J Geol Sci 3(1):71-80

18. Olorunfemi MO, Mesida EA (1987) Engineering geophysics and its application in engineering site investigationcase study from lle-lfe area. Niger Eng 22(2):57-66

19. Olorunfemi MO, Ojo JS, Sonuga FA, Ajayi O, Oladapo MI (2000) Geoelectric and electromagnetic investigation of the failed Koza and Nassarawa earth dams around Katsina, northern Nigeria. J Min Geol 36(1):51-65

20. Rahaman MA (1989) Review of the basements geology of south western Nigeria. In: Kogbe CA (ed) Geology of Nigeria. Elizabeth Publishing, Nigeria, pp 39-56

21. Reynolds JM (1997) An introduction to applied and environmental geophysics. John Wiley and Sons Ltd., England, p 132

22. Smyth AJ, Montgomery RF (1962) Soil and land use in central Western Nigeria. Government Printer, Ibadan, p 265

23. Telford WM, Geldart LP, Sheriff RE (1990) Applied Geophysics, 2nd edn. Cambridge University Press, Cambridge

24. Vander Velper BPA (1988) Resist version 1.0,1-D resistivity depth sounding interpretation software. Unpublished M.Sc. Research project. ITC, Delft Netherlands

25. Woods WR, Adeox JW (2002) A general characterization of pavement system failures with emphasis on a method for selecting repair process. J Constr Educ 7(1):58-62

\section{Submit your manuscript to a SpringerOpen ${ }^{\circ}$ journal and benefit from:}

- Convenient online submission

- Rigorous peer review

- Open access: articles freely available online

- High visibility within the field

- Retaining the copyright to your article

Submit your next manuscript at $\mathbf{s p r i n g e r o p e n . c o m ~}$ 